\title{
Characterisation of yeast and filamentous fungi from Brøggerbreen glaciers, Svalbard
}

\section{Purnima Singh and Utpal Roy}

Department of Biological Sciences, Birla Institute of Technology and Science (BITS), Pilani-K.K. Birla Goa Campus, Zuarinagar, Goa 403726, India (utpalroybitsgoa@ gmail.com)

\author{
Masaharu Tsuji \\ National Institute of Polar Research (NIPR), 10-3, Midori-machi, Tachikawa-shi, Tokyo, \\ 190-8518, Japan.
}

Received February 2015; first published online 7 March 2016

\begin{abstract}
Cryoconite holes have ecological and biotechnological importance. This article presents results on culturable cryophilic yeasts and filamentous fungi isolated from cryoconite holes at Austre and Vestre Brøggerbreen glaciers, Svalbard. Based on DNA sequence data, these were identified as Rhodotorula sp., Thelebolus sp., and Articulospora tetracladia. Amongst these, Articulospora tetracladia (88.7-89.4\% gene similarity with 5.8S rDNA) is a novel species, yet to be described. Filamentous fungus Articulospora sp. Cry-FB1 and Cry-FB2, expressed high amylase, cellulase, lipase and protease activities while yeast Rhodotorula sp. Cry-FB3 showed high amylase and cellulase activity. Thelebolus sp. Cry-YB 240 and Cry-YB 241 showed protease and urease activities. The effects of temperature, and salt on the growth of the cultures were studied. Optimum temperature of growth was on $10^{\circ} \mathrm{C}$ at $\mathrm{pH}$ 7.0. Filamentous fungi and yeast in the cryoconite holes possibly drive the process of organic macromolecule degradation through cold-adapted enzyme secretion, thereby assisting in nutrient cycling in these supraglacial environments. Further, these cryophilic fungi, due to their enzyme producing ability, may provide an opportunity for biotechnological research in the Arctic.
\end{abstract}

\section{Introduction}

Cryoconite holes are variously shaped, water filled depressions that are distributed over the glaciers of polar, alpine and other mountainous areas of the world. These holes are the biologically active niches within glacial ecosystems (Säwström and others 2002). These contain soft, dark coloured granular material, mostly consisting of both organic and inorganic matter. The organic matter mainly includes algae, bacteria, (Takeuchi and others 2001; Säwström and others 2002; Anesio and others 2009; Kastovska and others 2005; Hodson and others 2008; Edwards and others 2011; Singh and others 2013a) and rotifers, while the inorganic matter is a mixture of minerals and trace elements (Singh and others 2012). Recently, Singh and Singh (2012) characterised yeast and filamentous fungi from cryoconite holes of Midre Lovénbreen glacier, Svalbard. Further, and subsequently, a novel species Rhodotorula svalbardensis was reported from cryconites (Singh and others 2014). Edwards and others (2013) analysed fungi from cryoconites of Austre Brøggerbreen (AB), Midre Lovénbreen (ML) and Vestre Brøggerbreen (VB) glaciers with terminalrestriction fragment length polymorphism (T-RFLP) profiles, and recorded the presence of Articulospora and Varicosporium through a cultured approach. However, studies on fungal community inhabiting cryoconite holes on glaciers in Svalbard are still scanty.

Cryoconite holes work as mico-ecosystems and have ecological and biotechnological importance. To date there has been no study on the enzyme producing ability of cryophilic fungi from cryoconites of Brøggerbreen glaciers of Svalbard, Arctic. This study aims to address this knowledge gap by characterising the fungi inhabiting these glaciers cryoconites.

\section{Materials and methods}

\section{Study area and sample collection}

Samples were collected from Brøggerbreen glaciers (Austre and Vestre) (Fig 1a). Cryoconite samples were collected from different locations of glaciers in ablation zone. Austre Brøggerbreen $\left(11.7 \mathrm{~km}^{2}\right)$ and Vestre Brøggerbreen $\left(5.3 \mathrm{~km}^{2}\right)$ glaciers are situated on the western part of Spitsbergen, Svalbard. These two glaciers are the main sources of water to the Bayelva river (also known as Red river) finally merging into Kongsfjorden. Cryoconites were collected into sampling bags following strict contamination-free procedures (using a sterile gloves, syringe and sterile HiMedia sample collector), transported to laboratory with dry ice and stored at $-20^{\circ} \mathrm{C}$ until processed.

\section{Isolation of yeast and filamentous fungi}

One gram of cryoconite sediment was processed following the serial dilution method (Waksman 1916) and plated on mycological media MEA (malt extract agar, pH 5.5), PDA (potato dextrose agar, pH $5.6 \pm 0.2$ ), SDA (Sabouraud dextrose agar, pH 5.6) and PCA (potato carrot agar, pH $6.8 \pm 0.2$ ) (HiMedia India), by pour plate as well as spread plate techniques. Plates were incubated in triplicates at $4,15,22$ and $25^{\circ} \mathrm{C}$ for $2-4$ weeks. Culture plates were monitored regularly and on the basis of shape, colour, and different morphological features (hyphae, conidiophore, and conidial structure). The distinct colony 


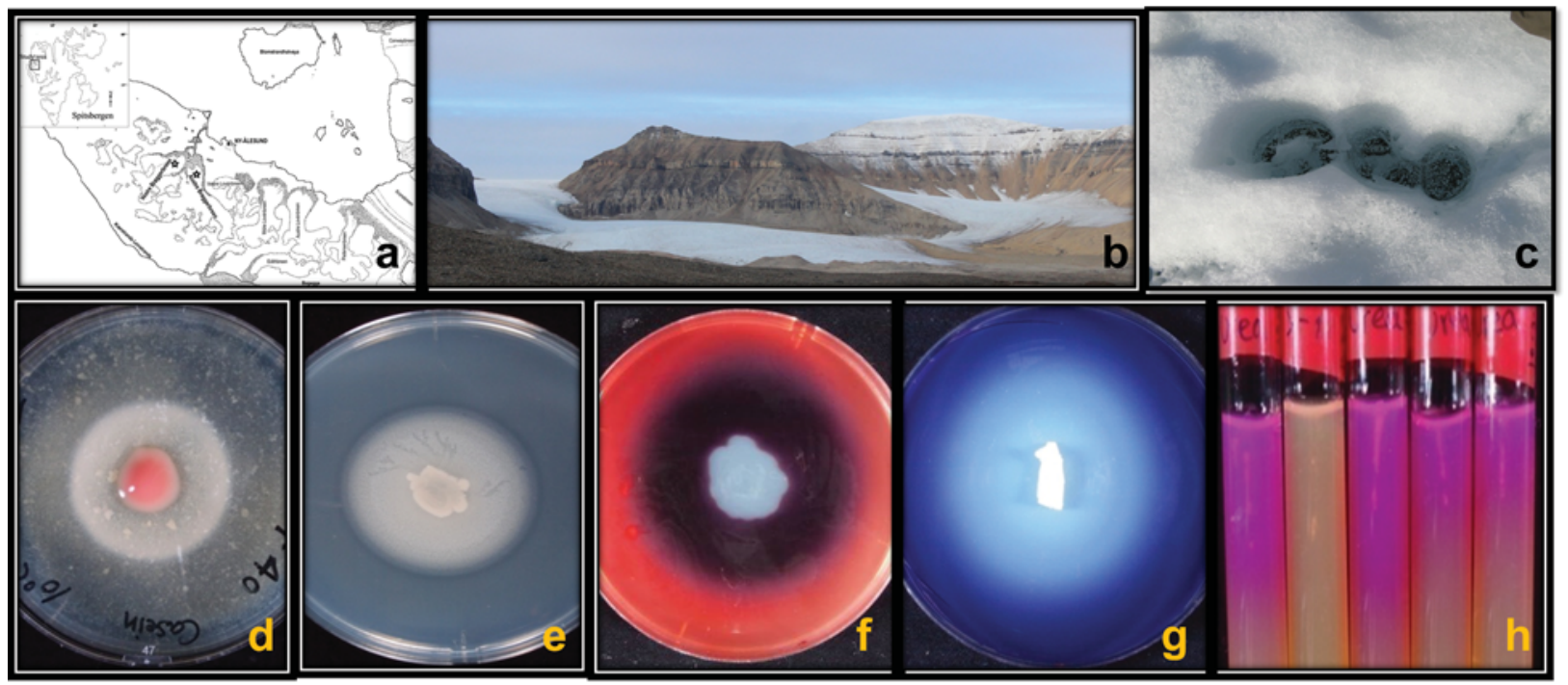

Fig. 1. a) Map showing the sampling areas, b) Landscape of Vestre Brøggerbreen glacier in Svalbard Arctic, c) Cryoconite holes d) protease activity e) lipase activity f) cellulase activity g) amylase activity h) urease activity.

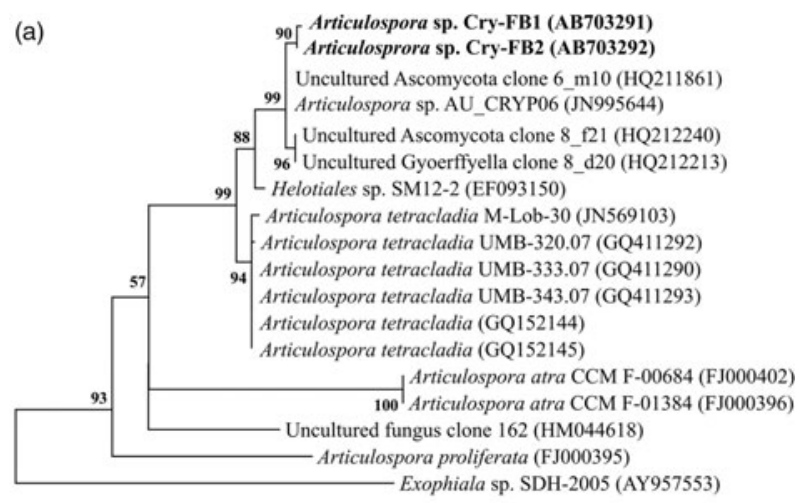

0.05

Fig. 2a. Phylogenetic analysis of Articulospora sp. using ITS region. The accession numbers of isolates are shown in parentheses. Tree was constructed with neighborjoining method. The significance of each branch is indicated by a bootstrap value. The scale bar is estimated substitutions per nucleotide position.

was picked up, sub cultured, and observed for purity of cultures under a microscope. The purified fungal colonies were transferred onto PDA slants (in a test tube at about a $35^{\circ}$ slant to provide more surface area for fungal growth), stored at $4^{\circ} \mathrm{C}$ for detailed study.

For morpho-taxonomical studies, the fungal mounts were prepared on slides using lactophenol-cotton blue as a mounting medium, and observed under Olympus BX51 and IX-71 model microscopes. Fungal cultures were initially identified on the basis of morphotaxonomy with the help of standard literatures (Ellis 1971, 1976; Barron 1977; Carmichael and others 1980; Kirk and others 2008; De Hoog and others 2005; Kurtzman and others 2011). The isolates with similar morphological characteristics were grouped together, and the representative isolates

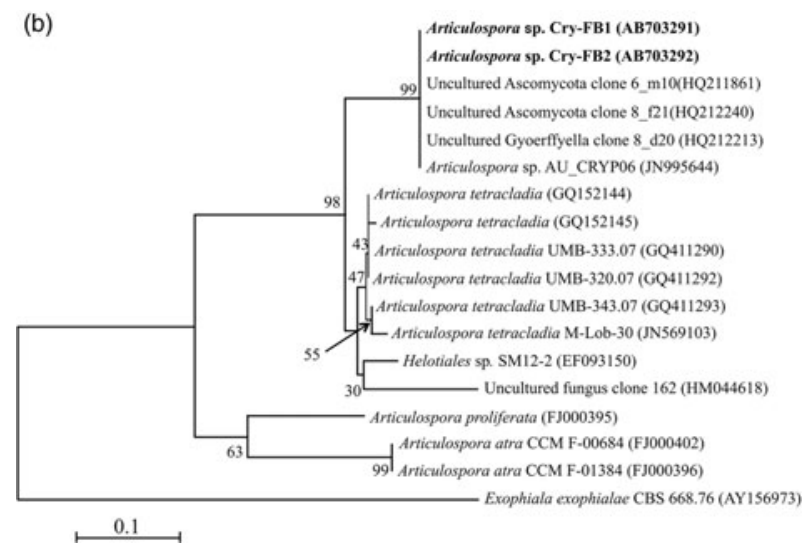

Fig. 2b. Phylogenetic analysis of Articulospora sp. using 5.8S rDNA region. The accession numbers of isolates are shown in parentheses. Tree was constructed with $\mathrm{NJ}$ method. The significance of each branch is indicated by a bootstrap value. The scale bar is estimated substitutions per nucleotide position.

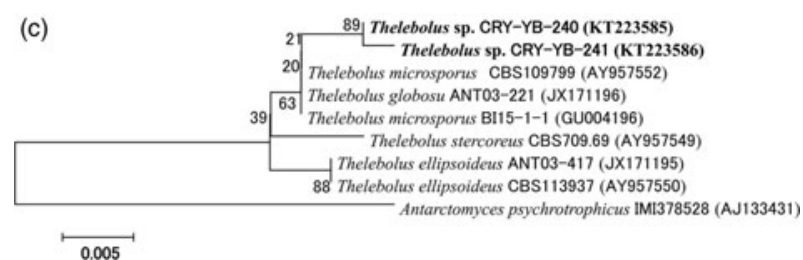

Fig. 2c. Phylogenetic tree of Thelebolus sp. using ITS region. The accession numbers of isolates are shown in parentheses. Tree was constructed with NJ method. The significance of each branch is indicated by a bootstrap value. The scale bar is estimated substitutions per nucleotide position.

were subjected to DNA sequence analysis. All identified pure cultures were maintained on PDA slants and deposited at the National Fungal Culture Collection of India (NFCCI-WDCM 932) in Pune, India. 
Table 1a. Identification of Articulospora species (using ITS region), total sequence lengths after alignment, \% sequence similarities, number of positions with base changes.

\begin{tabular}{|c|c|c|c|c|c|}
\hline $\begin{array}{l}\text { Sample } \\
\text { detail }\end{array}$ & $\begin{array}{l}\text { Sequence } \\
\text { deposition no. }\end{array}$ & $\begin{array}{l}\text { Total sequence } \\
\text { length }\end{array}$ & $\begin{array}{l}\text { No. of base } \\
\text { changes }\end{array}$ & $\begin{array}{l}\text { Bootstrap } \\
\text { support \% }\end{array}$ & $\begin{array}{l}\text { ITS region gene } \\
\text { sequences } \\
\text { similarity }(\%)\end{array}$ \\
\hline \multirow[t]{17}{*}{$\begin{array}{l}\text { Articulospora } \\
\text { sp. Cry-FB1 }\end{array}$} & $A B 703291$ & 553 & 9 & 99 & $\begin{array}{l}\text { Uncultured Ascomycota } \\
\text { clone 6_m10 } \\
\text { (HQ211861) by } 98.4 \% \text {. }\end{array}$ \\
\hline & & 543 & 8 & 99 & $\begin{array}{l}\text { Articulospora sp. } \\
\text { AU_CRYP06 (JN995644) } \\
\text { by } 98.5 \% \text {. }\end{array}$ \\
\hline & & 553 & 11 & 99 & $\begin{array}{l}\text { Uncultured Ascomycota } \\
\text { clone 8_f21 (HQ212240) } \\
\text { by } 98.0 \% \text {. }\end{array}$ \\
\hline & & 553 & 11 & 99 & $\begin{array}{l}\text { Uncultured Gyoerffyella } \\
\text { clone } 8 \text { d20 (HQ212213) } \\
\text { by } 98.0 \% \text {. }\end{array}$ \\
\hline & & 553 & 25 & 88 & $\begin{array}{l}\text { Helotiales sp. SM12-2 } \\
\text { (EF093150) by } 95.5 \% .\end{array}$ \\
\hline & & 514 & 30. & 94 & $\begin{array}{l}\text { Articulospora tetracladia } \\
\text { M-Lob-30 (JN569103) by } \\
94.2 \% \text {. }\end{array}$ \\
\hline & & 514 & 29 & 94 & $\begin{array}{l}\text { Articulospora tetracladia } \\
\text { UMB-320.07 } \\
\text { (GQ411292) by } 94.4 \% \text {. }\end{array}$ \\
\hline & & 514 & 28 & 94 & $\begin{array}{l}\text { Articulospora tetracladia } \\
\text { UMB-333.07 } \\
\text { (GQ411290) by } 94.6 \% \text {. }\end{array}$ \\
\hline & & 514 & 28 & 94 & $\begin{array}{l}\text { Articulospora tetracladia } \\
\text { UMB-343.07 } \\
\text { (GQ411293) by } 94.6 \% \text {. }\end{array}$ \\
\hline & & 554 & 32 & 94 & $\begin{array}{r}\text { Articulospora tetracladia } \\
\text { (GQ152144) by } 94.2 \% \text {. }\end{array}$ \\
\hline & & 554 & 33 & 94 & $\begin{array}{r}\text { Articulospora tetracladia } \\
\text { (GQ152145) by } 94.0 \% .\end{array}$ \\
\hline & & 561 & 111 & 100 & $\begin{array}{l}\text { Articulospora atra CCM } \\
\text { F-00684 (FJ000402) by } \\
80.2 \% \text {. }\end{array}$ \\
\hline & & 551 & 111 & 100 & $\begin{array}{l}\text { Articulospora atra CCM } \\
\text { F-01384 (FJ000396) by } \\
79.9 \% \text {. }\end{array}$ \\
\hline & & 516 & 68. & 14 & $\begin{array}{l}\text { Uncultured fungus clone } \\
162(\mathrm{HM} 044618) \text { by } \\
86.8 \% \text {. }\end{array}$ \\
\hline & & 545 & 117 & 93 & $\begin{array}{l}\text { Articulospora proliferata } \\
\text { (FJ000395) by } 78.5 \% \text {. }\end{array}$ \\
\hline & & 420 & 119 & - & $\begin{array}{l}\text { Exophiala sp. SDH-2005 } \\
\text { (AY957553) by } 71.7 \% \text {. }\end{array}$ \\
\hline & & 553 & 6 & 100 & $\begin{array}{c}\text { Articulospora sp. Cry-FB2 } \\
\text { (AB703292) by } 98.9 \% .\end{array}$ \\
\hline
\end{tabular}

Molecular characterisation (polymerase chain reaction (PCR), sequencing and phylogenetic analysis)

Total DNA was extracted from cultures (grown on PDA for 3 weeks at $4^{\circ} \mathrm{C}$ ) using the ISOPLANT II kit (Wako pure chemical industries Ltd.,Japan). Extracted DNA was amplified by PCR method using KOD-plus DNA polymerase (Toyobo Co. Ltd. Japan). PCR was performed under following conditions: Initial denaturation at $95^{\circ} \mathrm{C}$ for 2 min followed by 35 cycles of each denaturation at $95^{\circ} \mathrm{C}$ for $1 \mathrm{~min}$, annealing at $52^{\circ} \mathrm{C}$ for $30 \mathrm{sec}$, elongation at $72^{\circ} \mathrm{C}$ for $1 \mathrm{~min}$ and final elongation was carried out at $72^{\circ} \mathrm{C}$ for $7 \mathrm{~min}$.

The ITS region was amplified using following primers: ITS1F (5'-GTA ACA AGG TTT CCG T) and ITS4 (5'-TCC TCC GCT TAT TGA TAT GC). The amplified DNA was purified using a Wizard ${ }^{\circledR}$ SV Gel and PCR Clean-Up System (Promega KK, Tokyo, Japan). The purified DNA was sequenced on ABI DNA Sequencer following standard protocol. 
Table 1b. Identification of Articulospora species (using 5.8S rDNA region), total sequence lengths after alignment, $\%$ sequence similarities, number of positions with base changes

\begin{tabular}{|c|c|c|c|c|c|}
\hline $\begin{array}{l}\text { Sample } \\
\text { detail }\end{array}$ & $\begin{array}{l}\text { Sequence } \\
\text { deposition no. }\end{array}$ & $\begin{array}{l}\text { Total sequence } \\
\text { length }\end{array}$ & $\begin{array}{l}\text { No. of base } \\
\text { changes }\end{array}$ & $\begin{array}{l}\text { Bootstrap } \\
\text { support \% }\end{array}$ & $\begin{array}{l}\text { 5.8S rDNA region gene } \\
\text { sequences } \\
\text { similarity (\%) }\end{array}$ \\
\hline \multirow[t]{16}{*}{$\begin{array}{r}\text { Articulospora } \\
\text { sp. Cry-FB1 }\end{array}$} & $A B 703291$ & 151 & 0 & 99 & $\begin{array}{l}\text { Uncultured Ascomycota } \\
\text { clone 6_m10 } \\
\text { (HQ211861) by } 100 \% \text {. }\end{array}$ \\
\hline & & 151 & 0 & 99 & $\begin{array}{l}\text { Articulospora sp. } \\
\text { AU_CRYP06 (JN995644) } \\
\text { by } 100 \% \text {. }\end{array}$ \\
\hline & & 151 & 0 & 99 & $\begin{array}{l}\text { Uncultured Ascomycota } \\
\text { clone } 8 \text { f21 (HQ212240) } \\
\text { by } 100 \% \text {. }\end{array}$ \\
\hline & & 151 & 0 & 99 & $\begin{array}{l}\text { Uncultured Gyoerffyella } \\
\text { clone } 8 \text { d20 (HQ212213) } \\
\text { by } 100 \% \text {. }\end{array}$ \\
\hline & & 151 & 15 & 30 & $\begin{array}{l}\text { Helotiales sp. SM12-2 } \\
\text { (EF093150) by } 90.1 \% \text {. }\end{array}$ \\
\hline & & 151 & 17 & 55 & $\begin{array}{l}\text { Articulospora tetracladia } \\
\text { M-Lob-30 (JN569103) by } \\
88.7 \% \text {. }\end{array}$ \\
\hline & & 151 & 16 & 43 & $\begin{array}{l}\text { Articulospora tetracladia } \\
\text { UMB-320.07 } \\
\text { (GQ411292) by } 89.4 \% \text {. }\end{array}$ \\
\hline & & 151 & 16 & 43 & $\begin{array}{l}\text { Articulospora tetracladia } \\
\text { UMB-333.07 } \\
\text { (GQ411290) by } 89.4 \% \text {. }\end{array}$ \\
\hline & & 151 & 15 & 55 & $\begin{array}{l}\text { Articulospora tetracladia } \\
\text { UMB-343.07 } \\
\text { (GQ411293) by } 90.1 \% \text {. }\end{array}$ \\
\hline & & 151 & 16 & 43 & $\begin{array}{r}\text { Articulospora tetracladia } \\
\text { (GQ152144) by } 89.4 \% .\end{array}$ \\
\hline & & 151 & 17 & 43 & $\begin{array}{l}\text { Articulospora tetracladia } \\
\text { (GQ152145) by } 88.7 \% \text {. }\end{array}$ \\
\hline & & 134 & 32 & 99 & $\begin{array}{l}\text { Articulospora atra CCM } \\
\text { F-00684 (FJ000402) by } \\
76.1 \% \text {. }\end{array}$ \\
\hline & & 134 & 32 & 99 & $\begin{array}{l}\text { Articulospora atra CCM } \\
\text { F-01384 (FJ000396) by } \\
76.1 \% \text {. }\end{array}$ \\
\hline & & 146 & 26 & 30 & $\begin{array}{l}\text { Uncultured fungus clone } \\
162 \text { (HM044618) by } \\
82.2 \% \text {. }\end{array}$ \\
\hline & & 146 & 44 & 63 & $\begin{array}{l}\text { Articulospora proliferata } \\
\text { (FJ000395) by } 69.9 \% .\end{array}$ \\
\hline & & 151 & 0 & 99 & $\begin{array}{c}\text { Articulospora sp. Cry-FB2 } \\
\text { (AB703292) by } 100 \% .\end{array}$ \\
\hline
\end{tabular}

The sequences of isolates were analysed using the NCBI database and BLAST. Sequence alignment of ITS region isolates, together with the homologous sequences (retrieved from Genbank) of closely related species, was performed using Clustal W option of MEGA software version 6.0 (Tamura and others 2013). Subsequently the DNA sequences of the four isolates (AB703291, AB703292, KT223585 and KT223586) were deposited in the data bank.

To calculate the sequence divergence, the matrix was analysed using the neighbour joining method (Saitou and Nei 1987), the Tamura-Nei model (Tamura and Nei 1993) and the Maximum Parsimony method (Tamura and others 2011). To represent the evolutionary history of the taxa, the bootstrap consensus tree was inferred from 1000 replicates (Felsenstein 1985). The pairwise alignment was performed using EMBOSS Matcher - Pairwise Sequence Alignment tool (www.ebi. ac.uk/Tools/psa/emboss_matcher/nucleotide.html).

\section{Screening for enzymatic activity}

The enzyme activity (amylase, cellulase lipase and protease) was determined at $1,4,10$, and $20^{\circ} \mathrm{C}$ according to established procedures (Hankin and Anagnostakis 
Table 2. Identification of Thelebolus species (using ITS region), total sequence lengths after alignment, \% sequence similarities, number of positions with base changes.

\begin{tabular}{|c|c|c|c|c|c|}
\hline $\begin{array}{l}\text { Sample } \\
\text { detail }\end{array}$ & $\begin{array}{l}\text { Sequence } \\
\text { deposition no. }\end{array}$ & $\begin{array}{l}\text { Total sequence } \\
\text { length }\end{array}$ & $\begin{array}{l}\text { No. of base } \\
\text { changes }\end{array}$ & $\begin{array}{l}\text { Bootstrap } \\
\text { support \% }\end{array}$ & $\begin{array}{l}\text { ITS region gene } \\
\text { sequences } \\
\text { similarity (\%) }\end{array}$ \\
\hline \multirow[t]{7}{*}{$\begin{array}{r}\text { Thelebolus sp. } \\
\text { CRY-YB-240 }\end{array}$} & \multirow[t]{7}{*}{ KT223585 } & 538 & 6 & 21 & $\begin{array}{l}\text { Thelebolus microsporus } \\
\text { CBS109799 (AY957552) } \\
\text { by } 98.9 \% \text {. }\end{array}$ \\
\hline & & 504 & 6 & 63 & $\begin{array}{l}\text { Thelebolus globosu } \\
\text { ANT03-221 (JX171196) } \\
\text { by } 98.8 \% \text {. }\end{array}$ \\
\hline & & 538 & 6 & 63 & $\begin{array}{l}\text { Thelebolus microsporus } \\
\text { Bl15-1-1 (GU004196) by } \\
98.9 \% \text {. }\end{array}$ \\
\hline & & 482 & 12 & 39 & $\begin{array}{l}\text { Thelebolus stercoreus } \\
\text { CBS709.69 (AY957549) } \\
\text { by } 97.5 \% \text {. }\end{array}$ \\
\hline & & 548 & 12 & 88 & $\begin{array}{l}\text { Thelebolus ellipsoideus } \\
\text { ANT03-417 (JX171195) } \\
\text { by } 97.8 \% \text {. }\end{array}$ \\
\hline & & 480 & 12 & 88 & $\begin{array}{l}\text { Thelebolus ellipsoideus } \\
\text { CBS113937 (AY957550) } \\
\text { by } 97.5 \% \text {. }\end{array}$ \\
\hline & & 1109 & 7 & 89 & $\begin{array}{l}\text { Thelebolus sp. } \\
\text { CRY-YB-241 (KT223586) } \\
\text { by } 99.4 \% \text {. }\end{array}$ \\
\hline
\end{tabular}

1975; Buzzini and Martini 2002). Urease activity was also tested on YNBG (6.7 g/l Yeast Nitrogen Base, 20g/l glucose) containing $1 \mathrm{~g} / 1$ urea solution ( $\mathrm{pH} 5.5$ ). The diameter of the clear zone was measured to apparently quantify the enzyme activity (Figs 1d-g). Change in color from orange to pink was considered positive (Kurtzman and others 2011).

\section{Results}

A total of 20 isolates was obtained which were representing two genera of yeasts and one filamentous fungi belonging to two classes: Ascomycota (Articulospora sp., Thelebolus sp.) and Basidiomycota (Rhodotorula sp.).

Sequencing of ITS region and subsequent BLAST search showed that isolates of Articulospora sp. CryFB1 and Cry-FB2 closely resembled Articulospora tetracladia M-Lob-30 (JN569103) by 94.2\%., A. tetracladia UMB-320.07 (GQ411292) by 94.4\%., A. tetracladia UMB-333.07 (GQ411290) by $94.6 \%$, A. tetracladia UMB-343.07 (GQ411293) by $94.6 \%$, A. tetracladia (GQvv152144) by $94.2 \%$, A. tetracladia (GQ152145) by $94.0 \%$ and with Articulospora sp. AU_CRYP06 (JN995644) by $98.5 \%$ (Fig. 2a, Table 1a).

To confirm the novelty of Articulospora sp. Cry-FB1 and Cry-FB2 strains, the sequences of a more stable region (5.8S rRNA) which has slower evolutionary change rates were further analysed. 5.8S rRNA region showed closest sequences similarity (\%) with Articulospora tetracladia M-Lob-30 (JN569103) by $88.7 \%$, A. tetracladia UMB-320.07 (GQ411292) by 89.4\%, A. tetracladia UMB-333.07 (GQ411290) by $89.4 \%$, A. tetracladia UMB-343.07 (GQ411293) by 90.1\%, A. tetracladia
(GQ152144) by $89.4 \%$ and A. tetracladia (GQ152145) by $88.7 \%$ (Fig 2b, Table 1b). These analyses confirmed that Articulospora sp. Cry-FB1 (AB703291) and CryFB2 (AB703292) are novel strains. In phylogenetic tree the isolates Articulospora sp. Cry-FB1 and Cry-FB2 presented as novel species are yet to be established. The total sequence lengths after alignment, \% sequence similarities, and number of positions with base changes are summarised in Tables $1 \mathrm{a}$ and $1 \mathrm{~b}$.

Sequence analyses of isolates Thelebolus sp. CRY-YB-240 (KT223585) and Thelebolus sp.CRY-YB241 (KT223586) resembled Thelebolus microsporus CBS109799 (AY957552). Rhodotorula sp. Cry-FB3 indicated their closest relationship to the species of Rhodotorula svalbardensis Cry-YB-1 (AB734690). The phylogenetic tree of Thelebolus sp. is shown in Fig. 2c. The total sequence lengths after alignment, $\%$ sequence similarities, and number of positions with base changes of Thelebolus sp. CRY-YB-240, Thelebolus sp.CRY-YB-241 and closely related strains are shown in Table 2.

Most of the fungi isolated from the $\mathrm{AB}$ and $\mathrm{VB}$ glaciers cryoconites were capable of growing between 1 and $25^{\circ} \mathrm{C}$, indicating that fungi are cryophilic in nature. Isolates have shown salt tolerance ranging from $1-7 \%$ $\mathrm{NaCl}$. It was worth investigating the potential of Articulospora $\mathrm{sp}$, Rhodotorula $\mathrm{sp}$. and Thelebolus $\mathrm{sp}$. in terms enzyme production. The filamentous fungus like Articulospora sp., expressed high amylase, cellulase, lipase and protease activities whereas yeast Rhodotorula sp. showed high amylase and cellulase activity. Thelebolus sp. showed protease and urease activities (Table 3). The 
Table 3. Screening of fungal isolates for enzymes ability from Austre and Vestre Brøggerbreen glaciers of Svalbard.

\begin{tabular}{|c|c|c|c|c|c|c|c|c|c|c|c|c|c|c|c|c|c|c|c|c|c|}
\hline \multirow{2}{*}{$\begin{array}{l}\text { Culture } \\
\text { Code }\end{array}$} & \multirow{2}{*}{$\begin{array}{l}\text { Identification } \\
\text { of strains }\end{array}$} & \multicolumn{4}{|c|}{ Protease (casein) } & \multicolumn{4}{|c|}{ Lipase (Esterase) } & \multicolumn{4}{|c|}{ Cellulase } & \multicolumn{4}{|c|}{ Amylase } & \multicolumn{4}{|c|}{ Urease } \\
\hline & & $1^{\circ} \mathrm{C}$ & $4^{\circ} \mathrm{C}$ & $10^{\circ} \mathrm{C}$ & $20^{\circ} \mathrm{C}$ & $1^{\circ} \mathrm{C}$ & $4^{\circ} \mathrm{C}$ & $10^{\circ} \mathrm{C}$ & $20^{\circ} \mathrm{C}$ & $1^{\circ} \mathrm{C}$ & $4^{\circ} \mathrm{C}$ & $10^{\circ} \mathrm{C}$ & $20^{\circ} \mathrm{C}$ & $1^{\circ} \mathrm{C}$ & $4^{\circ} \mathrm{C}$ & $10^{\circ} \mathrm{C}$ & $20^{\circ} \mathrm{C}$ & $1^{\circ} \mathrm{C}$ & $4^{\circ} \mathrm{C}$ & $10^{\circ} \mathrm{C}$ & $20^{\circ} \mathrm{C}$ \\
\hline Cry-FB1 & $\begin{array}{l}\text { Articulospora } \\
\text { sp. }\end{array}$ & + & + & ++ & ++ & - & + & w & + & + & + & ++ & - & + & + & + & ++ & - & + & + & - \\
\hline Cry-FB2 & $\begin{array}{l}\text { Articulospora } \\
\text { sp. }\end{array}$ & + & + & ++ & ++ & + & ++ & + & + & + & + & ++ & + & + & + & - & ++ & - & + & + & - \\
\hline Cry-FB3 & $\begin{array}{l}\text { Rhodotorula } \\
\text { sp. }\end{array}$ & + & + & + & w & + & + & + & + & + & + & $++*$ & - & + & + & + & ++ & - & w & + & - \\
\hline $\begin{array}{c}\text { Cry-YB } \\
240\end{array}$ & Thelobolus sp. & + & - & ++ & w & - & + & - & + & - & - & - & - & + & + & - & - & - & + & - & + \\
\hline $\begin{array}{c}\text { Cry- YB } \\
241\end{array}$ & Thelobolus sp. & - & - & - & w & - & - & - & - & - & - & + & - & + & + & - & + & - & $++*$ & ++ & - \\
\hline
\end{tabular}

++, Strong positive; +, Positive; W, weak; -, Negative.

[Halo zone size $(1 \mathrm{~mm}-15 \mathrm{~mm})=+,(16-20 \mathrm{~mm} \&$ above $)=++]$ 
change in colour from orange to pink (Kurtzman and others 2011) was considered positive (Fig. 1h).

\section{Discussion}

Literature on culturable fungal diversity and biotechnological potential of isolates from glacier cryconites is scarce. Recently, Singh and Singh (2012) reported five genera (Cryptococcus, Mrakia, Rhodotorula., Phialophora and Articulospora) from ML glacier, while Edward and others (2013) reported two genera (Articulospora and Varicosporium) from $\mathrm{AB}, \mathrm{ML}$ and VB glaciers. In this study, fungi from three genera (Articulospora, Thelebolus, Rhodotorula) from $\mathrm{AB}$ and VB glaciers were isolated and their enzymatic potential analysed. The ecological role of these fungi in the cryoconite holes possibly drive the process of organic macromolecule degradation through enzyme secretion, thereby assisting in nutrient cycling in these supraglacial environments. Edward and others (2013) mentioned the role of Articulospora and Varicosporium as decomposers in the carbon dynamics of cryoconite holes.

The capability of subsisting at the midst of cryoconite holes at low temperatures $\left(0.1-1.5^{\circ} \mathrm{C}\right)$, and maintaining physiological processes depend on the biomacromolecules like enzymes that are cold-active. Most of the catabolic and anabolic reactions are energy consuming process and possibly the enzymes produced by the fungal isolates (Articulospora, Thelebolus, Rhodotorula) help them in cold adaptation mechanism and survival in oligotrophic glacier environment. The role of psychrophilic enzymes in cold adaptation has been reported earlier (Feller 2003; Lonhienne and others 2000). There are various interactions at the subcellular level, in which certain enzymes act as inducers for chains of further processes which are related to precursors of other reaction chains (Booth 1999; Orange 1994). During extreme environmental conditions, enzymes regulate the osmotic status of the cell by producing sugars, sugar alcohols, and polyols. Thus, enzyme producing ability of fungal isolates of cryoconites has an ecological significance.

The yeast colonies isolated from cryoconites showed orange and brown colour due to the presence of pigments which probably play some roles in maintaining the membrane fluidity. It is known that the modulation of membrane fluidity is brought about by changing the levels of polar and non-polar carotenoids (Jagannadham and others 2000). Thus, it seems that the pigments interacting with cell membranes increase its rigidity and enable cold-adaptation in cryoconite environment.

The screening results for various enzymes such as amylase, cellulase, lipase, protease, and urease of the isolates exhibited strong enzyme activities. These enzymes from $\mathrm{AB}$ and VB glaciers fungi promise biotechnological potentials. Studies on the cold-active enzymes from the polar regions are still fragmentary (Bej and Mojib 2009; Männistö and Häggblom 2006; Medigue and others 2005, Singh and others 2013b) although they find applications in health, agriculture and industry (Feller and Gerday 2003). Further studies on purification and characterisation of enzymes of these fungal isolates (Articulospora, Thelebolus, Rhodotorula) would provide better understanding about the biotechnological potentials, and its application in health, agriculture and industry.

Based on DNA sequence analyses, Articulospora sp. Cry-FB1 (AB703291) and Articulospora sp. Cry-FB2 (AB703292) are potentially novel strains with little 5.8S rDNA sequence homology to known species. Characterisation of these putative novel species of Articulospora svalbardensis sp. nov. will be addressed in a separate study.

\section{Acknowledgments}

We would like to thank the Directors, BITS, NIPR and NCAOR for facilities. Authors are thankful to Department of Science and Technology (DST) India for providing the financial support [SR/WOSA/LS-419/2013(G)]. The authors also acknowledge Dr. S.M. Singh of Polar Biology Laboratory, National Centre for Antarctic Ocean $\&$ Research (NCAOR) Goa for his valuable suggestions.

\section{References}

Anesio, A.M., A.J. Hodson, A. Fritz and others. 2009. High microbial activity on glaciers: importance to the global carbon cycle. Global Change Biology 15:955-960.

Barron, G.L. 1977. The genera of hyphomycetes from soil. New York: Robert E. Krieger Pub. Comp, INC.

Bej, A.K. and N. Mojib. 2009. Cold adaptation in Antarctic biodegradative microorganisms. In: Bej, A.K., J. Aislabie, and R.M. Atlas (editors). Polar microbiology: the ecology, biodiversity and bioremediation potential of microorganisms in extremely cold environments. Boca Raton: CRC Press: 157-177.

Booth, I.R. 1999. Adaptation to extreme environments. In: Lengeler, J.W., G. Drews and H.G. Schlegel. (editors). Biology of the Prokaryotes. Stuttgart: Thieme: 652-671.

Buzzini, P. and A. Martini. 2002. Extracellular enzymatic activity profiles in yeast and yeast-like strains isolated from tropical environments. Journal of Applied Microbiology 93:10201025

Carmichael, J.W., W. BryceKendrick, I.L. Connersand and L. Sigler. 1980. Genera of hyphomycetes. Canada: The University of Alberta Press.

De Hoog, G.S., E. Gottlich, G. Platas and others. 2005. Evolution, taxonomy and ecology of the genus Thelebolus in Antarctica. Studies in Mycology 51:33-76.

Edwards, A., A.M. Anesio, S.M. Rassner and others. 2011. Possible interactions between bacterial diversity, microbial activity and supraglacial hydrology of cryoconite holes in Svalbard. The ISME Journal 5:150-160.

Ellis, M.B. 1971. Dematiaceous hyphomycetes. Kew: CMI.

Ellis, M.B. 1976. More dematiaceous hyphomycetes. Kew: CMI.

Edwards, A., B. Douglas, A.M. Anesio and others. 2013. A distinctive fungal community inhabiting cryoconite holes on glaciers in Svalbard. Fungal Ecology 6: 168-176.

Feller, G. and C. Gerday. 2003. Psychrophile enzymes: hot topics in cold adaptation. Nature Reviews Microbiology 1: 200-208. 
Felsenstein, J. 1985. Confidence limits on phylogenies: an approach using the bootstrap. Evolution 39:783-791.

Hankin, L. and S.L. Anagnostakis. 1975. The use of solid media for detraction of enzyme production by fungi. Mycologia 67:97-607.

Hodson, A., A.M. Anesio, M. Tranter and others. 2008. Glacial ecosystems. Ecological Monographs. 78:41-67.

Jagannadham, M.V., M.K. Chattopadhyay, C. Subbalakshmi and others. 2000. Carotenoids of an Antarctic psychrotolerant bacterium Sphingobacterium antarcticus and a mesophilic bacterium Sphingobacterium multivorum. Archives of Microbiology 173:418-424.

Kastovska, K., J. Elster, M. Stibal and H. Santruckova. 2005. Microbial assemblages in soil microbial succession after glacial retreat in Svalbard (high Arctic). Microbial Ecology 50:396-407.

Kirk, P.M., P.F. Cannon, D.W. Minter and other. 2008. Ainsworth and Bisby's dictionary of the fungi. 10th Edn. Wallingford UK: CABI Publishing.

Kurtzman, C.P., J.W. Fell and, T. Boekhout. 2011. The yeasts, a taxonomic study. 5th Edn. Tokyo: Elsevier.

Lonhienne, T., C. Gerday and G. Feller. 2000. Psychrophilic enzymes: revisiting the thermodynamic parameters of activation may explain local flexibility. Biochimica et Biophysica Acta 1543:1-10.

Männistö, M. and M.M. Häggblom. 2006. Characterization of psychrotolerant heterotrophic bacteria from Finnish Lapland. Systematic and Applied Microbiology 29:229-243.

Medigue, C., E. Krin, G. Pascal and others. 2005. Coping with cold: the genome of the versatile marine Antarctica bacterium Pseudoalteromonas haloplanktis TAC125. Genome Research 15: 1325-1335.

Orange, N. 1994. Growth temperature regulates the induction of betalactamase in Pseudomonas fluorescens through modulation of the outer membrane permeation of a beta-lactaminducing antibiotic. Microbiology 140: 3125-3130.

Saitou, N. and M. Nei. 1987. The neighbor-joining method: A new method for reconstructing phylogenetic trees. Molecular Biology and Evolution 4:406-425.

Säwström, C., P. Mumford, W. Marshall and others. 2002. The microbial communities and primary productivity of cryoconite holes in an Arctic glacier (Svalbard $79^{\circ} \mathrm{N}$ ). Polar Biology 25:591-596.

Singh, P. and Singh, S.M. 2012. Characterization of yeast and filamentous fungi isolated from cryoconite holes of Svalbard, Arctic. Polar Biology 35:575-583.

Singh, S.M., J. Sharma, P. Gawas and others. 2012. Atmospheric deposition studies of heavy metals in Arctic by comparative analysis of lichens and cryoconite. Environmental Monitoring and Assessment DOI:10.1007/s10661-012-2638-5.

Singh, P., S.M. Singh, P. Dhakephalkar. 2013a. Diversity, cold active enzymes and adaptation strategies of bacteria inhabiting glacier cryoconite holes of High Arctic. Extremophiles DOI: 10.1007/s00792-013-0609-6.

Singh, P., M. Tsuji, S.M. Singh and others. 2013b. Taxonomic characterization, adaptation strategies and biotechnological potential of cryophilic yeasts from ice cores of Midre Lovénbreen glacier, Svalbard, Arctic. Cryobiology 66: 167-175.

Singh, P., S.M. Singh, M. Tsuji and others. 2014. Rhodotorula svalbardensis sp. nov., a novel yeast species isolated from cryoconite holes of Ny-Ålesund, Arctic. Cryobiology 68: 122128.

Takeuchi, N., S. Kohshima and K. Seko. 2001. Structure, formation, and darkening process of albedo-reducing material (cryoconite) on a Himalayan glacier: a granular algal mat growing on the glacier. Arctic, Antarctic, and Alpine Research 33: $115-122$.

Tamura, K., D. Peterson, N. Peterson and others. 2011. MEGA5: molecular evolutionary genetics analysis using maximum likelihood,evolutionary distance, and maximum parsimony methods. Molecular Biology and Evolution DOI: 10.1093/molbev/msr121

Tamura, K., G. Stecher, D. Peterson and others. 2013. MEGA6: Molecular evolutionary genetics analysis version 6.0. Molecular Biology and Evolution DOI:10.1093/molbev/mrs121.

Tamura, K. and M. Nei.1993. Estimation of the number of nucleotide substitutions in the control region of mitochondrial DNA in humans and chimpanzees. Molecular Biology and Evolution 10:512-526.

Waksman, S.A. 1916. Do fungi live and produce mycelium in the soil? Science NS 44:320-322. 